ISSN: 1858-4837; E-ISSN: 2598-019X

Volume 15, Nomor 1 (2020),

https://jurnal.uns.ac.id/region

DOI: $10.20961 /$ region.v15i1.24976

\title{
Partisipasi masyarakat dalam program pengelolaan sungai (Studi kasus: Sungai Pepe, Sungai Anyar, dan Sungai Premulung, Kota Surakarta)
}

\author{
Community participation in river management programs (Case study: Sungai \\ Pepe, Sungai Anyar, and Sungai Premulung, Surakarta)
}

\author{
A Mumpuni ${ }^{1}$, P Rahayu ${ }^{1}$, dan E F Rini ${ }^{1}$ \\ ${ }^{1}$ Program Studi Perencanaan Wilayah dan Kota, Fakultas Teknik, Universitas Sebelas \\ Maret
}

Corresponding author's email: anasmumpuni@gmail.com

\begin{abstract}
Abstrak. Pengelolaan sungai yang kompleks dan bersifat multisektor memerlukan tata kelola yang kolaboratif dalam penyelesaian masalahnya. Keterlibatan berbagai pihak menjadi penting dalam tata kelola yang kolaboratif. Masyarakat sebagai salah satu pihak terkait dalam pengelolaan sungai memiliki pengaruh yang penting. Penelitian ini bertujuan untuk menemukenali bentuk partisipasi masyarakat dalam program pengelolaan sungai yang dilakukan di Kota Surakarta. Metode analisis yang digunakan adalah analisis statistik deskriptif berdasarkan pada kuesioner. Penelitian ini menunjukkan bentuk partisipasi masyarakat dalam tiap program pengelolaan sungai yang dilakukan. Bentuk-bentuk partisipasi yang ada diidentifikasi ke dalam empat tahap, yaitu tahap perencanaan, pelaksanaan, pemanfaatan, dan pengawasan/evaluasi. Dari penelitian yang dilakukan, diketahui bahwa selama ini, mayoritas masyarakat berpartisipasi dalam tahap pelaksanaan dan pemanfaatan hasil. Partisipasi masyarakat hanya pada kedua tahap tersebut karena kurangnya penginformasian terkait program dan tidak adanya kesempatan untuk berpartisipasi dalam beberapa tahapan. Partisipasi masyarakat dipengaruhi oleh kondisi sosial ekonomi masyarakat, penginformasian program, tokoh masyarakat, dan kesempatan berpartisipasi dalam program.
\end{abstract}

Kata Kunci: Partisipasi Masyarakat; Pengelolaan Sungai; Statistik Deskriptif; Sungai; Tata Kelola Kolaboratif

Abstract. River management, which is complex and multisectoral, needs collaborative governance in solving problems. Involvement from various parties in 
collaborative governance is neccesary. Community has important impact as one part of river management. This research is aiming to identify community participation in river management program that has been done in Surakarta. Statistic descriptive analysis is used based on questionnaire. This study shows community participation form in every river management program that has been done. Participation form is defined in four stages, i.e. planning, implementation, utilization, and monitoring/evaluation. The result shows that most of the community has been take a part in implementation dan utilization stage of the river management programs. Community participation is only at these two stages due to lack of information related to the program and lack of opportunities to participate in several stages. These participation depend on community social economic condition, program information, community leaders, and opportunity to participate in the programs.

Keywords: Collaborative Governance; Community Participation; Descriptive Statistic; River; River Management

\section{Pendahuluan}

Sungai merupakan elemen penting yang menghubungkan lingkungan kota dan desa yang dimanfaatkan oleh manusia serta makhluk hidup lainnya [1]. Segala tindakan yang dilakukan terhadap sungai akan menimbulkan dampak perubahan sifat dan keadaan sebagai penyesuian terhadap perlakuan apa yang diterimanya [2]. Berbagai aktivitas manusia dalam memenuhi kebutuhan hidupnya yang berasal dari kegiatan industri, rumah tangga, dan pertanian akan ikut mempengaruhi kondisi dari sungai [3]. Sementara itu, perubahan kondisi kualitas air pada aliran sungai merupakan dampak dari buangan dari penggunaan lahan yang ada [4]. Perilaku masyarakat terhadap sungai juga ikut menyumbang terjadinya pencemaran [5].

Permasalahan pencemaran membuat sungai tidak bisa langsung dimanfaatkan sebagai sumber air bersih. Pemerintah Kota Surakarta mulai melakukan pengembangan sistem penyediaan air bersih dengan memanfaatkan air baku dari permukaan Sungai Bengawan Solo beserta anak-anak sungainya [6]. Berdasarkan data Badan Lingkungan Hidup (BLH) Kota Surakarta [7], pencemaran sungai di Solo sudah melebihi ambang batas baku mutu dan berada pada KMA Kelas 3 dan 4. Penyebab utama dari pencemaran sungai di Surakarta adalah limbah domestik, limbah industri batik, dan limbah home industry tahu tempe $[7,8]$. Pengelolaan sungai harus melibatkan berbagai pihak terkait karena pengelolaan tidak hanya berasal dari satu pihak saja. Perencanaan partisipatif adalah proses perencanaan yang diwujudkan dalam musyawarah ini, dimana sebuah rancangan rencana dibahas dan dikembangkan bersama semua pelaku stakeholders [9]. Perencanaan partisipatif adalah metode perencanaan pembangunan dengan cara melibatkan warga masyarakat yang diposisikan sebagai obyek pembangunan [10]. Masyarakat sebagai pengguna lahan di sekitar sungai harus ikut dilibatkan. Dalam pengelolaan sungai dengan paradigma partisipatoris semua pihak perlu untuk dilibatkan. Keterlibatan masyarakat pun menjadi salah satu kunci utama dalam paradigma ini. 
Menurut Soetomo [11], partisipasi masyarakat dapat terbagi menjadi beberapa bentuk, yaitu partisipasi masyarakat dalam perencanaan program pembangunan, partisipasi masyarakat dalam mewujudkan hasil dari perencanaan yang dibuat, partisipasi masyarakat dalam memanfaatkan hasil pembangunan yang telah dijalankan, dan partisipasi masyarakat dalam evaluasi yang diwujudkan dengan menilai dan mengawasi kegiatan pembangunan serta hasil-hasilnya. Adapun partisipasi masyarakat dipengaruhi oleh 2 faktor utama, yaitu faktor internal dan faktor eksternal. Faktor internal merupakan kondisi sosial dan ekonomi masyarakat [12-16]. Faktor eksternal yang mempengaruhi partisipasi diantaranya komunikasi, tokoh masyarakat, dan kesempatan untuk berpartisipasi [17].

Sungai Pepe, Sungai Anyar, dan Sungai Premulung menjadi sungai yang memiliki pengaruh yang sangat besar bagi Kota Surakarta dan Sungai Bengawan Solo sendiri karena langsung bermuara di Sungai Bengawan Solo yang akan dimanfaatkan sebagai sumber air baku Kota Surakarta (Gambar 1). Pengelolaan sungai yang baik diperlukan demi terwujudnya rencana pengembangan tersebut. Pengelolaan sungai merupakan suatu hal yang kompleks dan bersifat multisektor. Kerjasama berbagai pihak, dalam hal ini pemerintah, swasta, dan masyarakat dapat diartikan sebagai collaborative governance. Keterlibatan masyarakat penting dalam memperbaiki kualitas sumber air bersih di Kota Surakarta. Akan tetapi, karena kompleksitas permasalahan, pengelolaan yang dilakukan tidak bisa sepenuhnya didasarkan inisiatif masyarakat. Bentuk agency-driven atau partisipasi yang didasarkan pada program top-down paling sesuai untuk digunakan saat isu dihadapi kompleks [18].

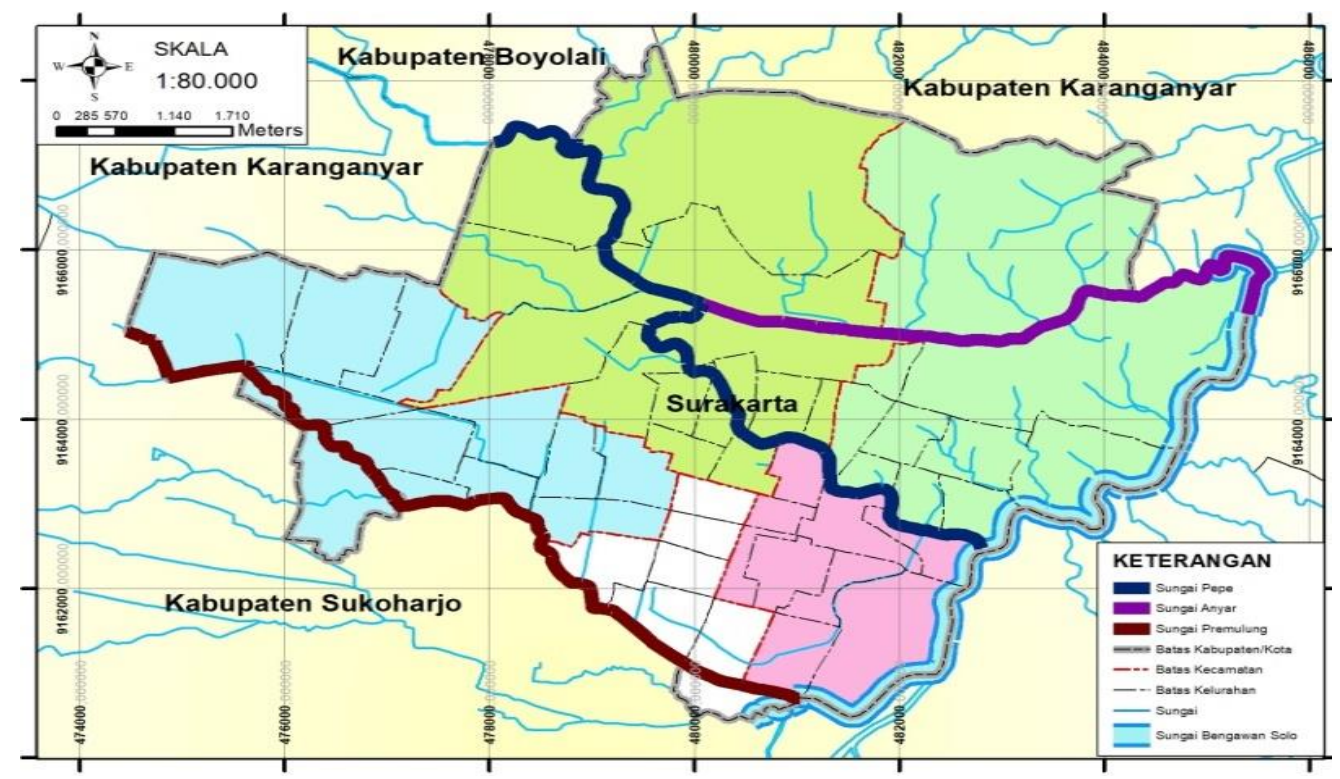

Gambar 1. Peta sungai obyek penelitian.

Berdasarkan permasalahan yang muncul terkait pengelolaan sungai di Kota Surakarta yang sudah dijabarkan, maka perlu untuk melihat bentuk partisipasi yang telah dilakukan masyarakat selama ini. Penelitian ini memiliki perbedaan dengan penelitian-penelitian yang sudah ada sebelumnya, dimana penelitian sebelumnya hanya mencakup substansi pelaksanaan program. Di lain pihak, penelitian ini mengkaji sejauh mana bentuk keterlibatan 
masyarakat dalam program pengelolaan sungai bersifat top-down yang dilakukan di Kota Surakarta.

\section{Metode}

Penelitian yang dilakukan menggunakan pendekatan deduktif yang menggunakan logika untuk menarik kesimpulan yang didasarkan dari pengamatan yang dilakukan. Jenis penelitian yang digunakan merupakan penelitian kuantitatif, dimana data yang digunakan sebagai alat analisis berupa angka [19]. Data akan diukur dengan menggunakan metode statistik deskriptif. Statistik deskriptif digunakan untuk menganalisis data dengan cara mendeskripsikannya untuk menarik kesimpulan yang berlaku secara umum. Pengumpulan data dilakukan dengan survei primer berupa kuesioner terbuka dengan responden masyarakat bantaran Sungai Pepe, Sungai Anyar, dan Sungai Premulung, serta pelaku UKM dan home industry tahu tempe. Kerangka analisis yang digunakan sebagai panduan pada penelitian ini diilustrasikan pada Gambar 2.

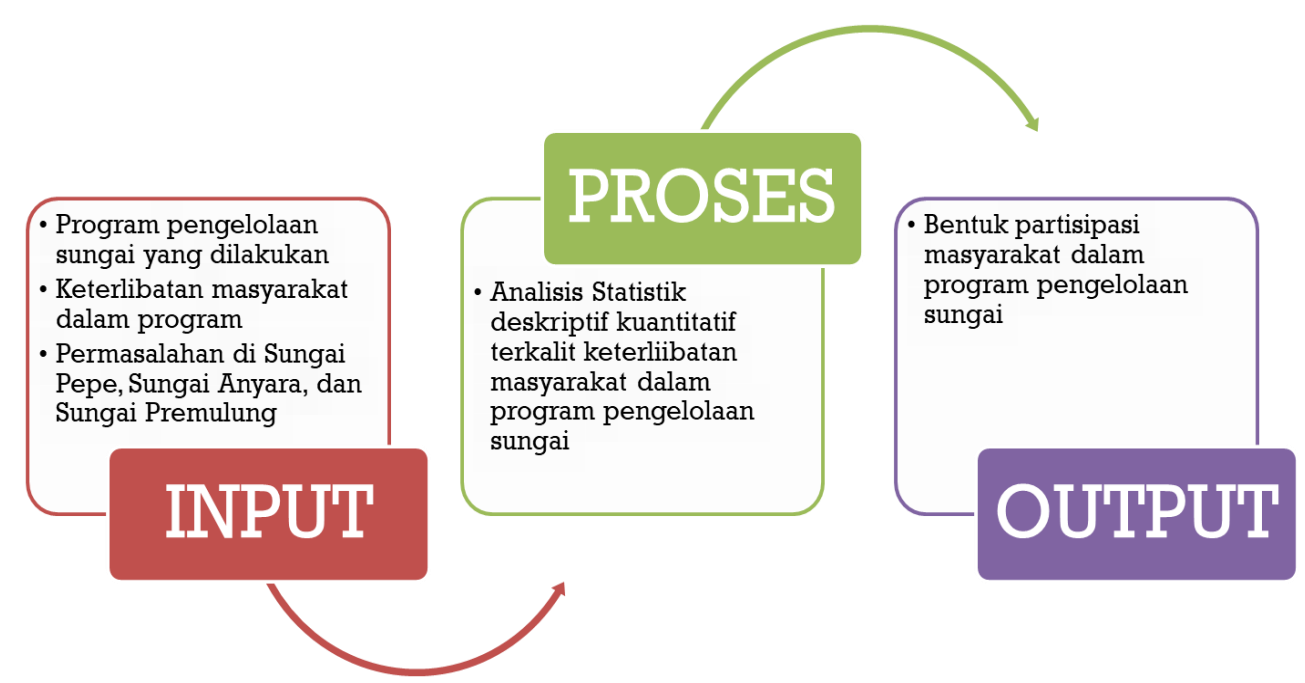

Gambar 2. Kerangka analisis penelitian.

Pengelolaan sungai akan selalu mempertimbangkan kondisi dari sungai. Kondisi sungai diidentifikasi dari dua hal yaitu keadaan fisik dan keadaan masyarakat. Keadaan fisik sungai ini digunakan untuk melihat permasalahan yang ada di sungai tersebut. Pengelolaan sungai dilakukan dalam bentuk program pengelolaan. Keterlibatan masyarakat menjadi hal penting dalam program pengelolaan sungai. Bentuk keterlibatan masyarakat dapat berupa pengambilan keputusan, pelaksanaan, pemanfaatan, dan evaluasi. Variabel dalam penelitian secara detail disebutkan pada Tabel 1. 
Tabel 1. Perumusan variabel penelitian.

\begin{tabular}{ll}
\hline \multicolumn{1}{c}{ Variabel } & \multicolumn{1}{c}{ Subvariabel } \\
\hline Keadaan Fisik Sungai & $\begin{array}{l}\text { Geometris } \\
\text { Penggunaan lahan } \\
\text { Pencemaran } \\
\text { Sosial } \\
\text { Ekonomi } \\
\text { Keadaan masyarakat di sekitar sungai }\end{array}$ \\
& Kelembagaan \\
Bentuk partisipasi masyarakat dalam pembuatan & - \\
kebijakan & \\
Bentuk partisipasi masyarakat dalam pelaksanaan & - \\
program & \\
Bentuk partisipasi masyarakat dalam pemanfaatan hasil & \\
Bentuk partisipasi masyarakat dalam evaluasi program & - \\
\hline
\end{tabular}

\section{Hasil penelitian dan pembahasan}

\subsection{Karakteristik Sungai}

Sungai Pepe, Sungai Anyar, dan Sungai Premulung mewakili pencemaran yang ada di Kota Surakarta. Selain itu, ketiga sungai ini memiliki pengaruh yang besar terhadap kualitas air Sungai Bengawan Solo karena langsung bermuara di sungai tersebut. Sungai Pepe terbagi menjadi dua, yaitu Pepe Hulu dan Pepe Hilir. Sungai Pepe Hulu memiliki panjang 2,75 km dan Sungai Pepe Hilir sepanjang 5,76 km. Pencemaran yang terjadi di Sungai Pepe didominasi oleh limbah rumah tangga. Kualitas air Sungai Pepe Hulu masuk ke dalam kelas III, sedangkan Sungai Pepe Hilir masuk ke dalam kelas IV.

Sungai Anyar berawal dari Tirtonadi hingga Tempuran membentang sepanjang 6,3 km. Terdapat pencemaran dari limbah rumah tangga dan home industry tahu tempe. Dengan kondisi tersebut, kualitas air Sungai Anyar masuk dalam kelas 4. Masyarakat di sekitar Sungai Anyar menyadari pula tentang kondisi air sungai tersebut dan menyatakan bahwa air Sungai Anyar tidak bisa dimanfaatkan untuk kebutuhan sehari-hari. Akan tetapi, mayoritas masyarakat belum menyadari bahwa air Sungai Anyar telah mengalami pencemaran yang parah. Sungai Premulung memiliki panjang $2,55 \mathrm{~km}$ dengan lebar $25-36 \mathrm{~m}$ dan kedalamannya mencapai $10-15 \mathrm{~m}$. Warna air sungai yang berubah serta bau dari sungai membuat masyarakat menyadari adanya pencemaran yang terjadi. Kondisi air membuat gatal meskipun hanya terkena sedikit. Mayoritas masyarakat menyatakan air Sungai Premulung tidak bisa dimanfaatkan untuk kegiatan sehari-hari.

\subsection{Program pengelolaan sungai}

3.2.1. Program kali bersih. Program Kali Bersih (PROKASIH) untuk mengendalikan pencemaran air sungai dan meningkatkan kualitas air sungai. Untuk mendukung terealisasinya program, dilakukan pembentukan Pokja Sungai yang ikut serta menjaga sungai, juga menumbuhkembangkan nilai kegotongroyongan dan kemasyarakatan serta meningkatkan peran serta masyarakat dalam perlindungan dan konservasi sungai. 


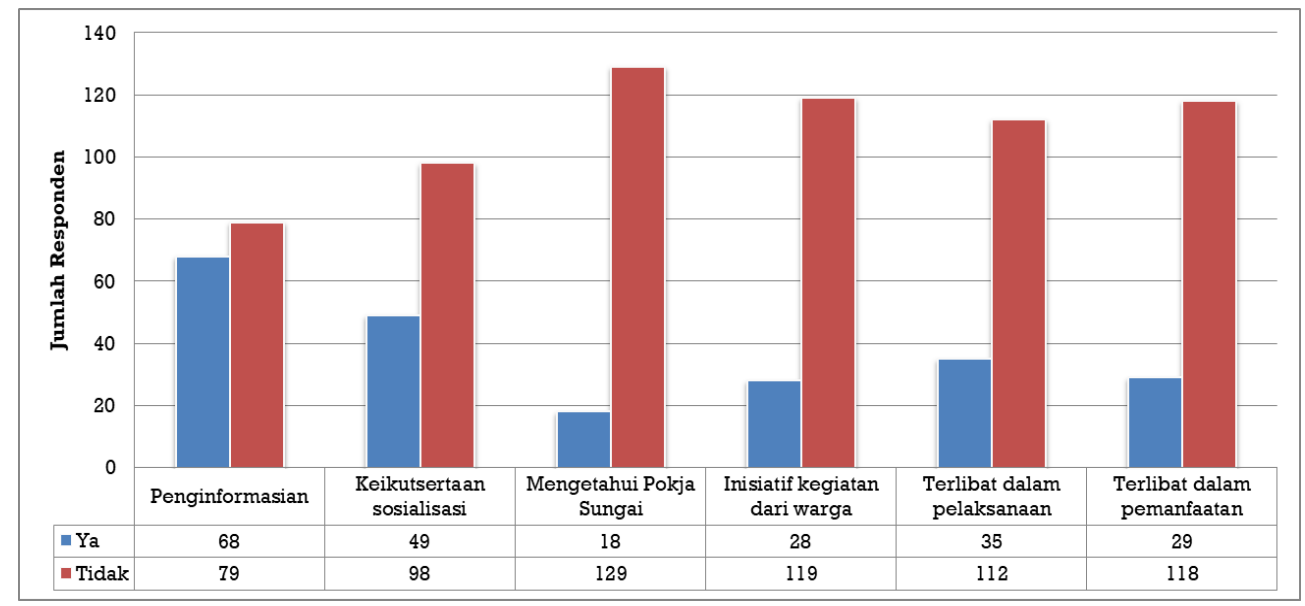

Gambar 3. Diagram partisipasi dalam program kali bersih.

Masyarakat yang mendapatkan informasi dan mengikuti sosialisasi terkait program lebih sedikit dibandingkan yang tidak mendapatkan informasi dan tidak mengikuti sosialisasi. Pengetahuan warga tentang adanya Pokja Sungai sangat rendah, hanya $12 \%$ saja yang mengetahuinya. Kegiatan terkait kebersihan sungai hanya sebagian kecil yang berasal dari inisiatif warga. Insiatif kegiatan kebersihan sungai bukan berasal dari warga yang tinggal di pinggiran sungai. Keterlibatan masyarakat dalam kegiatan program kali bersih pun sangat rendah. Hanya 35 dari 147 responden yang menyatakan terlibat dalam pelaksanaan program kali bersih, sisanya merasa bahwa mereka tidak terlibat dalam kegiatan (Gambar 3). Selama ini, masyarakat kurang terlibat dalam kegiatan pembersihan sungai. Sungai hanya dibersihkan oleh pekerja-pekerja proyek yang ada di sana maupun saat ada program kebersihan dari TNI dan ABRI. Masyarakat juga terlibat dalam pemanfaatan program dari segi sosial dan pribadi berupa lingkungan yang nyaman dan bersih untuk ditinggali. Hasil dari survei menginformasikan bahwa persentase masyarakat yang merasakannya masih rendah.

3.2.2. Saberling. Saberling merupakan singkatan dari Sapu Bersih Lingkungan. Kelompok ini dibentuk pada tingkat kelurahan untuk membangun rasa tanggungjawab masyarakat terhadap lingkungannya. Lewat kelompok ini diharapkan masyarakat aktif melakukan pembersihan dan pengawasan lingkungan. Program ini merupakan program baru yang dilaksanakan pada tahun 2018 ini.

Penginformasian terkait program saberling masih sangat minim. Hanya sedikit masyarakat yang mengetahui tentang adanya saberling. Dalam inisiatif kegiatan saberling sekalipun, mayoritas menyatakan bahwa inisiatif bukan berasal dari warga, hanya $6 \%$ dari masyarakat yang memiliki inisiatif terhadap program. Keterlibatan masyarakat dalam kegiatan terkait pelaksanaan saberling pun sangat rendah. Warga masyarakat yang menyatakan merasakan manfaat dari program ini lebih rendah dibandingkan yang tidak merasakan manfaat dari program. Dari hasil survei, dapat disimpulkan bahwa masyarakat ikut terlibat dalam tahap pelaksanaan dan pemanfaatan tapi dalam persentase yang sangat rendah (Gambar 4). 


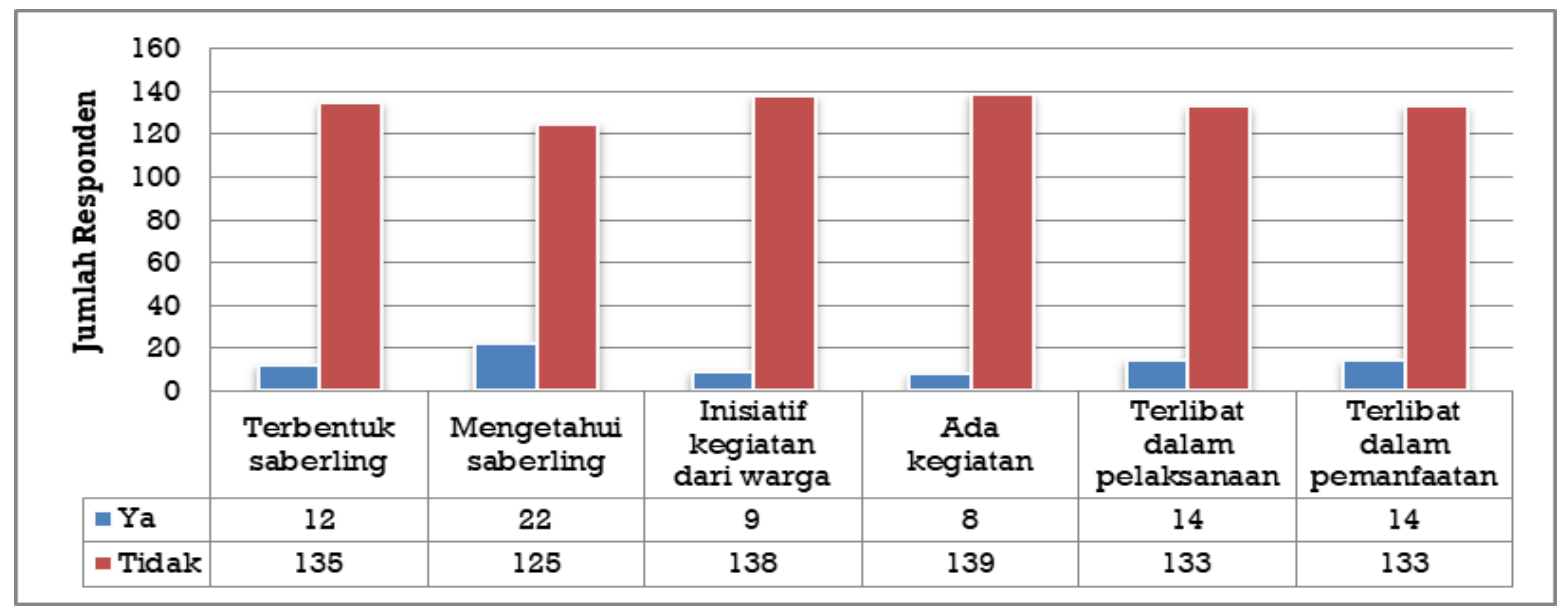

Gambar 4. Diagram partisipasi dalam program Saberling.

3.2.3. Produksi bersih, pengolahan limbah, dan pengendalian pencemaran. Sosialisasi ini dilaksanakan pada tahun 2017 dan 2018 yang menargetkan para pelaku usaha yang menghasilkan limbah terutama limbah cair. Pelaksanaan pada tahun 2017 khusus diperuntukan bagi peserta dari kelompok UKM Batik. Hal ini terkait dengan tingginya angka pencemaran yang diakibatkan dari UKM ini terutama di Sungai Premulung [8].

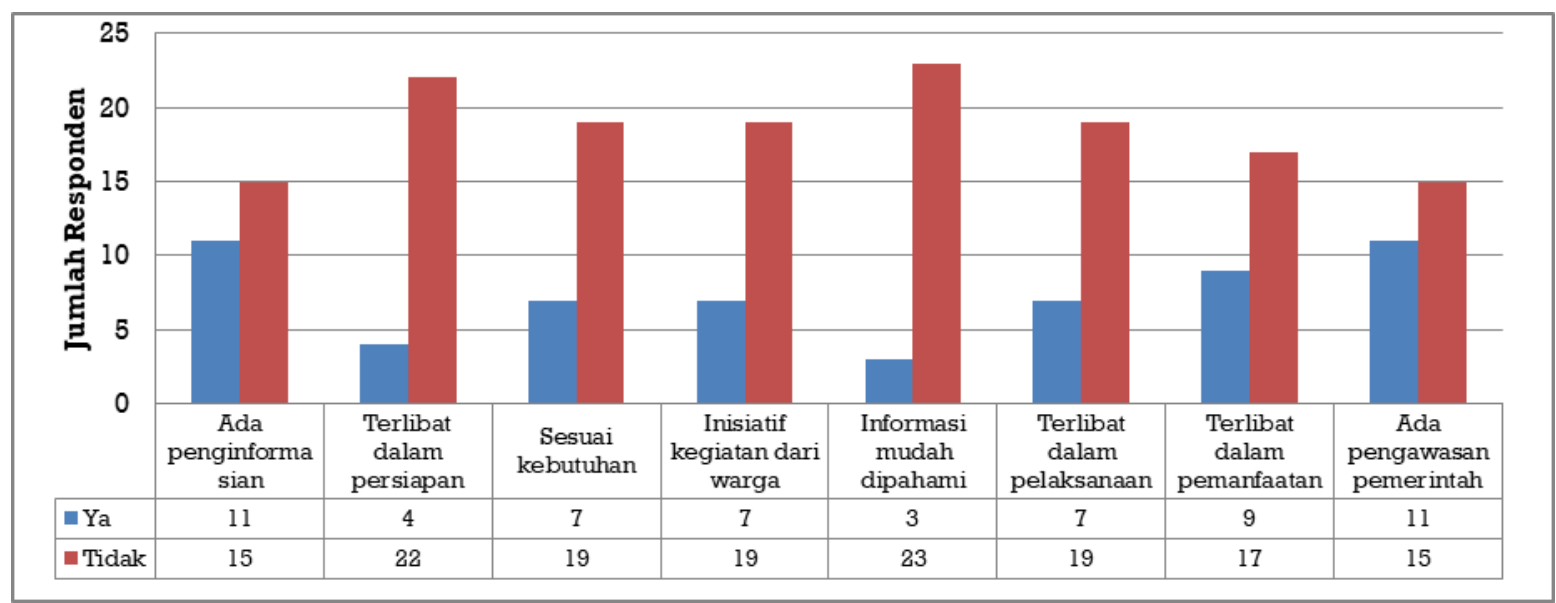

Gambar 5. Diagram partisipasi dalam program produksi bersih, pengolahan limbah, dan pengendalian pencemaran.

Informasi terkait program tidak diketahui oleh seluruh masyarakat. Terdapat masyarakat yang tidak mengetahui adanya penginformasian dan sosialisasi terkait program. Program yang diberikan masih banyak dipandang oleh masyarakat tidak sesuai dengan kebutuhan. Informasi yang diberikan masih kurang bisa dipahami dan dimengerti. Karena hal tersebut, sebagian besar masyarakat tidak terlibat dalam pelaksanaan porgram yang diberikan. Tidak terdapat tindak lanjut secara nyata terkait program. Keterlibatan masyarakat dalam kegiatan program produksi bersih, pengolahan limbah, dan pengendalian pencemaran tidak ada. Masyarakat juga menyatakan mereka merasakan manfaat dari program tetapi dalam kuantitas yang kecil. Dari hasil tersebut dapat disimpulkan bahwa masyarakat terlibat dalam 
pelaksanaan dan pemanfaatan hasil program (Gambar 5). Salah satu pemanfaatan hasil program dlH berupa social benefit dimana UKM yang menjalankan program tersebut menjadi UKM yang dipandang ramah lingkungan dan banyak dijadikan percontohan.

3.2.4. Pembangunan IPAL Laweyan. Pembangunan IPAL ini ditujukan untuk pengelolaan limbah UKM Batik yang ada di Kelurahan Laweyan dan Sondakan dimana sebagian besar limbahnya dibuang ke Sungai Premulung. IPAL Laweyan dibangun pada tahun 2007 dengan sebelumnya diadakan 4 kali pertemuan sosialisasi dengan warga.

Tabel 2. Partisipasi dalam pogram penyediaan IPAL di Sungai Premulung.

\begin{tabular}{|c|c|c|c|}
\hline No & Pernyataan & Jumlah & $\%$ \\
\hline \multicolumn{4}{|c|}{ Pengambilan keputusan program } \\
\hline 1 & Mengikuti & 6 & $60 \%$ \\
\hline 2 & Tidak Mengikuti & 4 & $40 \%$ \\
\hline & Total & 10 & $100 \%$ \\
\hline \multicolumn{4}{|c|}{ Keterlibatan dalam pelaksanaan program } \\
\hline 1 & Terlibat dalam kegiatan & 3 & $30 \%$ \\
\hline 2 & Tidak terlibat dalam kegiatan & 7 & $70 \%$ \\
\hline & Total & 10 & $100 \%$ \\
\hline \multicolumn{4}{|c|}{ Keberadaan KSM pengelola IPAL } \\
\hline 1 & Ada & 7 & $70 \%$ \\
\hline 2 & Tidak ada & 3 & $30 \%$ \\
\hline & Total & 10 & $100 \%$ \\
\hline \multicolumn{4}{|c|}{ Partisipasi masyarakat dalam penyediaan IPAL secara swadaya } \\
\hline 1 & Terdapat partisipasi & 6 & $60 \%$ \\
\hline 2 & Tidak terdapat partisipasi & 4 & $40 \%$ \\
\hline & Total & 10 & $100 \%$ \\
\hline
\end{tabular}

Seperti data yang ditunjukkan pada Tabel 2, partisipasi masyarakat cukup baik. Masyarakat banyak terlibat dalam perencanaan, terutama karena ide awal pengusulan IPAL dari masyarakat sendiri. Mayoritas masyarakat ikut terlibat dalam perencanaan program yang dilaksanakan lewat sosialisasi secara berkala. Keterlibatan masyarakat dalam pelaksanaan program masih minim karena perlunya kemampuan khusus untuk membuat IPAL hanya 30\% warga bisa ikut terlibat. Keterlibatan masyarakat terkait pengawasan dan evaluasi pembangunan IPAL pun baik. Masyarakat berinisiatif untuk mengajukan revitalisasi IPAL yang mengalami kerusakan akibat banjir tahun 2012. Meskipun masih harus digerakkan oleh tokoh masyarakat yang ada, namun masyarakat bersedia untuk ikut andil dalam tiap proses program.

3.2.5. Pembangunan bendung karet Tirtonadi. Proyek pembangunan bendung karet ini dilaksanakan oleh Balai Besar Wilayah Sungai (BBWS) Bengawan Solo dimulai tahun 2014. Pembuatan bendung ini bertujuan untuk mendukung terlaksananya rencana pengembangan wisata air di Sungai Pepe Hilir dengan menjaga volume air pada Sungai Pepe Hilir. Pertisipasi masyarakat dalam proses pembangunan bendung karet Tirtonadi dapat dilihat pada Tabel 3 . 
Tabel 3. Partisipasi dalam program pembangunan bendung karet Tirtonadi.

\begin{tabular}{lccccccccccc}
\hline $\begin{array}{c}\text { Terlibat } \\
\begin{array}{c}\text { pengambilan } \\
\text { keputusan } \\
\text { program }\end{array}\end{array}$ & Jumlah & $\%$ & $\begin{array}{c}\text { Terdapat } \\
\text { sosialisasi } \\
\text { terkait } \\
\text { program }\end{array}$ & Jumlah & $\%$ & $\begin{array}{c}\text { Terlibat dalam } \\
\text { pelaksanaan } \\
\text { program }\end{array}$ & Jumlah & $\%$ & $\begin{array}{c}\text { Warga } \\
\text { mengajukan } \\
\text { usulan }\end{array}$ & Jumlah & \% \\
\hline Ya & 4 & 67 & Ya & 6 & 100 & Ya & 1 & 17 & Ya & 1 & 17 \\
Tidak & 2 & 33 & Tidak & 0 & 0 & Tidak & 5 & 83 & Tidak & 5 & 83 \\
$\quad$ Jumlah & 6 & 100 & Jumlah & 6 & 100 & Jumlah & 6 & 100 & Jumlah & 6 & 100 \\
\hline
\end{tabular}

Program pembangunan Bendung Karet Tirtonadi dilaksanakan di Sungai Pepe Hulu. Semua masyarakat mengetahui tentang adanya program tersebut dan mengikuti sosialisasi yang dilaksanakan. Warga seluruhnya menyetujui tentang program yang ada. Hampir seluruh warga yang terdampak ikut terlibat dalam perencanaan program. Beberapa warga mengajukan usulan terkait perencanaan program. Sementara itu, masyarakat tidak banyak terlibat dalam pelaksanaan. Pelibatan masyarakat disesuaikan dengan kemampuannya. Bila terdapat warga yang bisa membantu dalam ikut membangun, diperbolehkan untuk ikut terlibat. Maka, dapat disimpulkan bahwa masyarakat telah berpartisipasi dalam tahapan perencanaan dan pelaksanaan dari program.

3.2.6. Penataan bantaran Sungai Pepe. Penataan bantaran Sungai Pepe ini dimaksudkan untuk menata bangunan yang memakan tempat di sempadan sungai, selain itu, juga dilakukan penataan terhadap ruang terbuka publik di sepanjang sempadan Sungai Pepe Hilir. Dengan adanya penataan ini diharapkan sempadan sungai menjadi bersih dan terbebas dari bangunan-bangunan sehingga memungkinkan untuk dijadikan jalur inspeksi dan memperkecil kemungkinan banjir dan mengurangi pencemaran dari rumah yang ada di bantaran sungai.

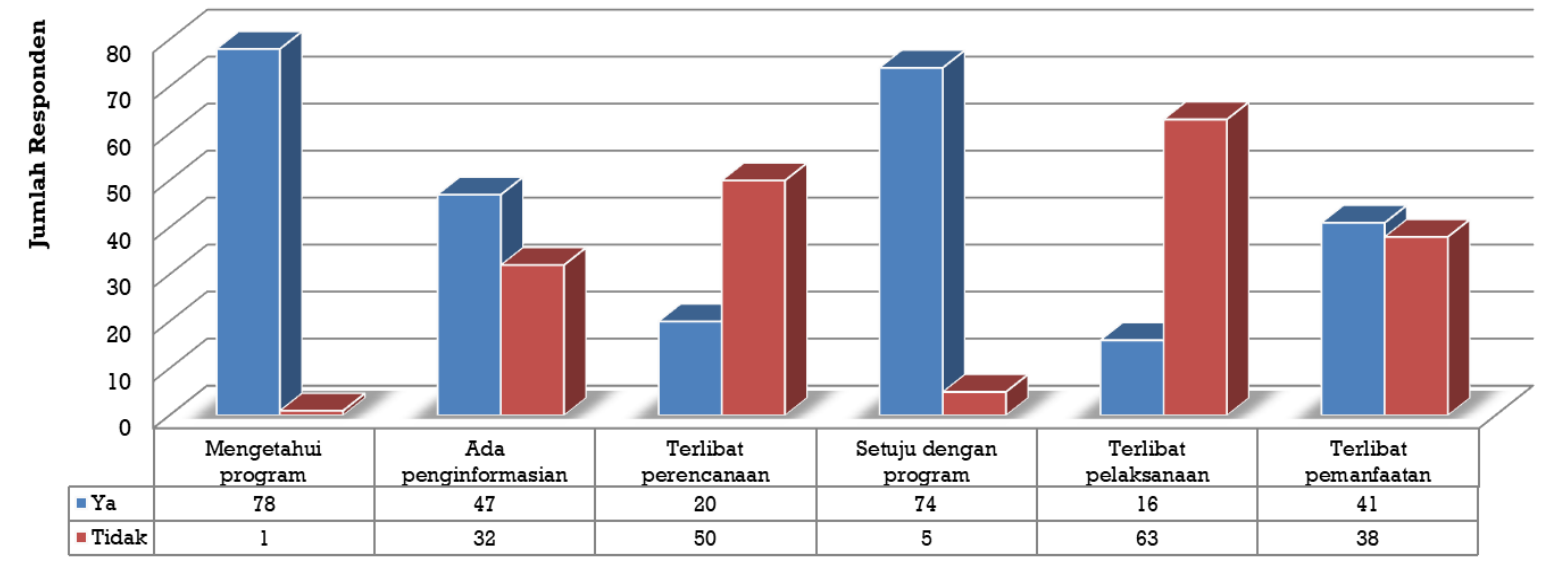

Gambar 6. Partisipasi dalam program penataan bantaran Sungai Pepe.

Hampir seluruh masyarakat bantaran sungai atau 99\% masyarakat mengetahui tentang adanya program penataan bantaran Sungai Pepe (Gambar 6). Akan tetapi, tidak semua warga penginformasian dilakukan dengan sosialisasi. Dalam perencanaan dan pembangunan warga masyarakat tidak banyak yang terlibat, mayoritas masyarakat hanya menyetujui saja rencana program dari pemerintah. Keterlibatan masyarakat dalam program yang ada pun 
masih sangat rendah, hanya $20 \%$ yang terlibat. Selama ini warga masyarakat hanya langsung mengalami dampak dari program pembangunan tanpa mengetahui tujuan maupun rincian program. Dapat disimpulkan bahwa masyarakat terlibat dalam semua tahapan partisipasi tapi dengan persentase keterlibatan yang tidak merata.

3.2.7. Program peningkatan pengelolaan sampah di Sungai Pepe. Program ini merupakan bagian dari penataan Sungai Pepe yang bertujuan untuk mengurangi pencemaran dari sampah yang langsung dibuang ke sungai. Hingga saat ini, pelaksanaan program hanya pada penyediaan tempat sampah yang dibedakan sesuai jenisnya, namun belum ada sosialisasi atau pemberitahuan kepada warga di sekitar lokasi terkait pemilahan sampah yang baik.

Tabel 4. Partisipasi dalam program peningkatan pengelolaan sampah.

\begin{tabular}{|c|c|c|c|}
\hline No & Pernyataan & Jumlah & $\%$ \\
\hline \multicolumn{4}{|c|}{ Pengetahuan warga tentang program } \\
\hline 1 & Mengetahui & 42 & $53 \%$ \\
\hline 2 & Tidak Mengetahui & 37 & $47 \%$ \\
\hline & Total & 79 & $100 \%$ \\
\hline \multicolumn{4}{|c|}{ Terdapat penginformasian program } \\
\hline 1 & $\mathrm{Ya}$ & 53 & $67 \%$ \\
\hline 2 & Tidak & 26 & $33 \%$ \\
\hline & Total & 79 & $100 \%$ \\
\hline \multicolumn{4}{|c|}{ Keterlibatan masyarakat dalam program } \\
\hline 1 & Ada & 27 & $34 \%$ \\
\hline 2 & Tidak & 52 & $66 \%$ \\
\hline & Total & 79 & $100 \%$ \\
\hline
\end{tabular}

Berdasarkan Tabel 4, diketahui sebagian besar masyarakat sudah mengetahui tentang program tersebut meskipun bukan dalam rangka penataan bantaran Sungai Pepe. Penginformasian tentang pemilahan sampah banyak didapatkan dari pihak swasta dan institusi pendidikan. Meskipun demikian, keterlibatan masyarakat dalam program hanya $34 \%$, mayoritas masyarakat masih belum melakukan pelaksanaan dari program ini.

\subsection{Partisipasi Masyarakat}

Terdapat partisipasi masyarakat dalam program pengelolaan sungai. Dapat disimpulkan bentuk partisipasi masyarakat selama ini sebagaimana dijelaskan dalam Tabel 5.

Bentuk partisipasi yang dilakukan masyarakat di tiap program pengelolaan sungai terdiri dari partisipasi dalam perencanaan, pelaksanaan, pemanfaatan, dan evaluasi/pengawasan. Bentuk partisipasi masyarakat ini sesuai dengan teori Kaho [20] yang mengatakan bahwa bentuk partisipasi yang dapat diberikan masyarakat antara lain partisipasi dalam proses pembuatan keputusan, partisipasi dalam pelaksanaan, partisipasi dalam memanfaatkan hasil, dan partisipasi dalam evaluasi. Kunci kesuksesan/keberhasilan partisipasi masyarakat dilihat pada adanya kepemimpinan yang baik dari tokoh kunci dalam masyarakat [21]. Dalam program pembangunan IPAL Laweyan yang dilaksanakan pada Sungai Premulung, masyarakat terlibat dalam semua bentuk partisipasi, mulai dari perencanaan hingga evaluasi/pengawasan program juga dalam program saberling serta produksi bersih, pengolahan limbah, dan pengendalian pencemaran, partisipasi didorong dengan adanya 
tokoh kunci ini. Keberadaan Forum Pengembangan Kampung Batik Laweyan menggerakan masyarakat di Sungai Premulung untuk ikut terlibat dalam program pengelolaan sungai. Partisipasi masyarakat pada program Saberling, PROKASIH, serta Produksi Bersih, Pengolahan Limbah, dan Pengendalian Pencemaran pada Sungai Anyar masih kurang bila dibandingkan dengan yang lain. Ketiadaan organisasi pendukung membuat partisipasi masyarakat kurang baik. Sesuai dengan pernyataan Korten (1983) dalam Hikmat [22] yang menyatakan hal penting yang ikut menentukan konsep pembangunan berbasis partisipasi masyarakat adalah kebutuhan akan kemampuan kelembagaan yang mampu membangun dan menggerakan masyarakat.

Tabel 5. Partisipasi masyarakat dalam program pengelolaan sungai.

\begin{tabular}{|c|c|c|c|c|c|}
\hline \multirow[b]{2}{*}{ No } & \multirow[b]{2}{*}{ Program } & \multicolumn{4}{|c|}{ Tahap } \\
\hline & & Perencanaan & Pelaksanaan & Pemanfaatan & $\begin{array}{c}\text { Evaluasi/ } \\
\text { Pengawasan }\end{array}$ \\
\hline 1 & PROKASIH & - & $v$ & $v$ & - \\
\hline 2 & Saberling & - & $v$ & $v$ & - \\
\hline 3 & $\begin{array}{l}\text { Produksi Bersih, Pengolahan Limbah, } \\
\text { dan Pengendalian Pencemaran }\end{array}$ & - & - & - & - \\
\hline 4 & $\begin{array}{l}\text { Pembangunan IPAL Laweyan dan } \\
\text { Sondakan }\end{array}$ & $v$ & - & - & - \\
\hline 5 & Pembangunan Bendung Karet Tirtonadi & $v$ & - & - & - \\
\hline 6 & Penataan Bantaran Sungai Pepe & - & - & - & - \\
\hline 7 & $\begin{array}{l}\text { Program Peningkatan Pengelolaan } \\
\text { Sampah di Sungai Pepe }\end{array}$ & - & - & - & - \\
\hline
\end{tabular}

Pada program PROKASIH, Saberling, Penataan Bantaran Sungai Pepe, dan Program Peningkatan Pengelolaan Sampah di Sungai Pepe, mayoritas warga masih belum mengetahui tentang adanya program tersebut. Bahkan untuk Program Peningkatan Pengelolaan Sampah di Sungai Pepe, masyarakat yang hanya terlibat pada tahap pelaksanaan program masih sedikit. Demikian pula untuk program Penataan Bantaran Sungai Pepe berupa perbaikan dinding sungai dan pemasangan pagar, mayoritas warga mengetahui tentang adanya program tersebut setelah mulai pembangunan. Hal ini menyebabkan keterlibatan masyarakat dalam program tersebut juga rendah. Rendahnya pengetahuan masyarakat tentang program sesuai dengan teori yang menyatakan bahwa tingkat penguasaaan informasi mengenai program merupakan faktor yang dapat menimbulkan kemauan seseorang untuk berpartisipasi [23]. Pada Program Penataan Bantaran Sungai Pepe, warga sama sekali tidak terlibat dalam pelaksanaan. Hal ini dikarenakan tidak adanya kegiatan yang bisa dilakukan warga untuk berpartisipasi dalam pelaksanaan program. Ketiadaan kesempatan berpartisipasi ini sesuai dengan teori yang menyatakan kesempatan yang mendorong individu untuk ikut berpartisipasi dalam program berupa pemberian akses [24].

Permasalahan yang dihadapi dalam pelaksanaan program adalah mayoritas warga yang masih tidak mengetahui tentang adanya program pengelolaan sungai yang dilakukan ataupun harusnya dilakukan. Dalam pelaksanaan program, pemerintah hanya melakukan pemberian informasi kepada stakeholder kunci dan tokoh masyarakat. Tokoh masyarakat diharapkan mampu untuk meneruskan informasi program yang didapat kepada seluruh 
masyarakat sehingga dapat mengerti tentang program tersebut dan bisa ikut berpartisipasi. Pada kenyataannya, tidak terdapat komunikasi kepada warga terkait program pengelolaan sungai yang diterapkan sehingga partisipasi masyarakat pun tidak bisa optimal. Persentase masyarakat yang ikut serta masih jauh lebih kecil dibandingkan yang tidak berpartisipasi. Selain itu, keterbatasan informasi program membuat masyarakat tidak bisa berpartisipasi dalam semua bentuk. Partisipasi yang dilakukan oleh masyarakat menjadi terbatas. Kondisi ini diperkuat dengan teori dari Suroso et al [14] yang menyatakan ada hubungan antara keaktifan berpartisipasi dengan tingkat komunikasi. Komunikasi yang intensif dengan warga masyarakat mampu meningkatkan partisipasi masyarakat.

\section{Kesimpulan}

Bentuk partisipasi masyarakat dalam program pengelolaan sungai terdiri dari partisipasi dalam pembuatan kebijakan (perencanaan), partisipasi dalam pelaksanaan, partisipasi dalam pemanfaatan hasil, dan partisipasi dalam evaluasi/pengawasan. Masyarakat tidak berpartisipasi dalam semua bentuk pada tiap program. Partisipasi masyarakat paling tinggi berada pada program pembangunan IPAL Laweyan dimana masyarakat berpartisipasi pada semua tahapan program. Sedangkan partisipasi masyarakat yang paling rendah ada di Program Peningkatan Pengelolaan Sampah di Bantaran Sungai Pepe. Masyarakat hanya terlibat dalam pelaksanaan dan hanya dalam kuantitas kecil. Perbedaan keterlibatan masyarakat di tiap program disebabkan oleh adanya faktor internal yang berasal dari masyarakat dan faktor eksternal berupa komunikasi, tokoh masyarakat, dan kesempatan berpartisipasi. Keberadaan tokoh masyarakat atau lembaga dalam masyarakat membantu untuk mendorong terjadinya partisipasi dalam program pengelolaan sungai. Keselarasan informasi terkait program pengelolaan sungai juga mempengaruhi keterlibatan masyarakat. Masyarakat yang mengetahui tentang program pengelolaan sungai cenderung aktif terlibat dalam semua bentuk partisipasi. Selain itu, kesempatan untuk berpartisipasi juga menjadi faktor pendukung masyarakat untuk terlibat dalam program pengelolaan sungai. Hal ini dapat dilihat dengan jelas pada Program Penataan Bantaran Sungai Pepe dimana warga belum memiliki kesempatan untuk berpartisipasi dalam pelaksanaan. Begitu pula dalam Program Saberling dan PROKASIH, masyarakat kurang difasilitasi untuk terlibat dalam perencanaan dan evaluasi program.

\section{Referensi}

[1] Itonaga, K 2005 The Nested Structure of Local Environment Architectural Institute of Japan (Ed.) Architecture for sustainable future (Tokyo: IBEC)

[2] Mulyanto 2007 Sungai dan Sifat-sifatnya (Yogyakarta: Penerbit Graha Ilmu)

[3] Suriawiria U 2003 Air dalam Kehidupan dan Lingkungan yang Sehat (Bandung: Penerbit Alumni)

[4] Tafangenyasha C dan Dzinomwa T 2005 Land-use Impact on River Water Quality in Lowveld Sand River System in South-East Zimbabwe Land-use and Water Resources Research 5 1-10 DOI: 10.22004/ag.econ.47961

[5] Dyah A, Sasongko S B, dan Sudarno 2012 Analisis Kualitas Air dan Strategi Pengendalian Pencemaran Air Sungai Blukar Kabupaten Kendal Jurnal PRESIPITASI 9 DOI: 10.14710/presipitasi.v9i2.64-71 
[6] Pemerintah Kota Surakarta 2012 Peraturan Daerah Kota Surakarta Nomor 1 tahun 2012 tentang Rencana Tata Ruang Wilayah Kota Surakarta Tahun 2011-2031

[7] Portal Berita Solopos 2016 BLH: Seluruh Sungai Di Solo Tercemar Sampah Rumah Tangga Diakses dari http://www.solopos.com/2016/03/06/pencemaran-solo-blhseluruh-sungai-di-solo-tercemar-sampah-rumah-tangga-698238 pada 3-10-2017

[8] Portal Berita Solopos 2017 Limbah Industri Batik Cemari Sungai-Sungai di Solo Diakses dari http://www.solopos.com/2017/10/03/limbah-industri-batik-cemari-sungaisungai-di-solo-856479 pada 3-10-2017

[9] Dwidjowijoto dan Wrihatnolo 2007 Manajemen Pemberdayaan: Sebuah Pengantar dan Panduan untuk Pemberdayaan Masyarakat (Jakarta: PT. Elex Media Komputindo)

[10] Sumarsono S 2010 Manajemen Keuangan Pemerintah (Yogyakarta: Graha Ilmu)

[11] Soetomo 2008 Strategi-strategi Pembangunan Masyarakat (Yogyakarta: Pustaka Pelajar)

[12] Inkeles A 1969 Making Man Modern: On the Causes and Consequenses of Individual Change in Six Developing Countries American Journal of Sociology 75 208-25 Diakses dari https://www.jstor.org/stable/2776103?seq=1 pada 06-01-2020

[13] Itta D et al 2009 Faktor-Faktor yang Berhubungan dengan Tingkat Partisipasi Masyarakat Sekitar Tambang PT Arutmin Indonesia Satui Mine dalam Pelaksanaan Program Aku Himung Petani Banua Jurnal Hutan Tropis Borneo 26 177-84 Diakses dari http://garuda.ristekdikti.go.id/documents/detail/96186 pada 06-01-2020

[14] Suroso H, Hakim A, dan Noor I 2014 Faktor-faktor yang Mempengaruhi Partisipasi Masyarakat dalam Perencanaan Pembangunan di Desa Banjaran Kecamatan Driyorejo Kabupaten Gresik Wacana 17 Diakses dari http://garuda.ristekdikti.go.id/documents/detail/272833 pada 06-01-2020

[15] Suryani M, Ahmad R R, dan Munir R 1987 Lingkungan: Sumber Daya Alam dan Kependudukan dalam Pembangunan (Jakarta: LIPI Press)

[16] Tjokroamidjojo B 1985 Perencanaan Pembangunan (Jakarta: Gunung Agung)

[17] Soelaiman H 1985 Partisipasi Masyarakat dalam Pembangunan Berencana (Bandung: BSSW)

[18] Steelman T A and Carmin J 2002 Community based watershed remediation: Connecting organizational resources to social and substantive outcomes Toxic waste and environmental policy in the 21st century United States ed. Rahm D chapter 7 145-78 (Jefferson: McFarland \& Company Inc.) Diakses dari https://www.researchgate.net/publication/265288355 Community-

Based Watershed Remediation Connecting Organizational Resources to Social a nd Substantive Outcomes pada 06-01-2020

[19] Kasiram M 2008 Metodologi Penelitian (Malang: UIN-Malang Pers)

[20] Kaho J R 2007 Prospek Otonomi Daerah di Negara Republik Indonesia (Identifikasi Faktor-Faktor yang Mempengaruhi Penyelenggaraan Otonomi Daerah) (Jakarta: PT. Raja Grafindo Persada)

[21] Setiawan B 2005 Hak Masyarakat dalam Proses Penyusunan dan Implementasi Kebijakan Tata Ruang Forum Perencanaan Pembangunan Januari 17-23 
[22] Hikmat H 2000 Analisis Dampak Lingkungan Sosial: Strategi Menuju Pembangunan Berpusat Pada Rakyat (People Centered Development) (Jakarta: Pascasarjana Manajemen Pembangunan Sosial)

[23] Lugiarti E 2004 Peningkatan Partisipasi Masyarakat dalam Proses Perencanaan Pengembangan Masyarakat di Komunitas Desa Cijayanti Tesis (Bogor: Institut Pertanian Bogor)

[24] Lokita D A 2011 Partisipasi Masyarakat dalam Program Pengelolaan Sampah (Kasus PT. Indosement Tunggal Prakarsa Tbk. di Desa Gunung Sari, Kecamatan Citeureup, Kabupaten Bogor) Skripsi Bogor: Institut Pertanian Bogor. Diakses dari http://repository.ipb.ac.id/handle/123456789/49964 pada 06-01-2020 